\title{
First record of Solea (Microchirus) boscanion (Osteichthyes: Soleidae) in the Mediterranean Sea, with data on other sympatric soleid species
}

\author{
Enric Massutí ${ }^{*}$, J.A. Reina-Hervás ${ }^{\dagger}$, Domingo Lloris ${ }^{\ddagger}$ and L. Gil de Sola \\ *IEO-Centre Oceanogràfic de les Balears, Moll de Ponent s/n, PO Box 291, 07080 Palma de Mallorca, Spain; and UIB-Departament \\ de Biologia, Campus Universitari, 07071 Palma de Mallorca, Spain. ${ }^{\dagger}$ Departamento Biología Animal, Facultad Ciencias, Universidad \\ Málaga, 29071 Málaga, Spain. ${ }^{\ddagger}$ CSIC-Institut de Ciències del Mar, Passeig Nacional s/n, 08039 Barcelona, Spain. IEO-Centro Ocea- \\ nográfico de Málaga, PO Box 285, 29640 Fuengirola, Spain. \\ ${ }_{\text {Corresponding author, e-mail: enric.massuti@ba.ieo.es }}$
}

The capture of five specimens of Solea (Microchirus) boscanion (Osteichthyes: Soleidae), a species previously unrecorded in the Mediterranean, is reported from the Iberian coast (western Mediterranean). The main morphometric and meristic measurements of this species with data of the other sympatric, and morphologically very similar, soleids Microchirus variegatus and Buglossidium luteum are also given. The record is discussed in relation to climate change and competition between species.

\section{INTRODUCTION}

Soleidae can be considered widely represented in the Mediterranean Sea, where 16 species are generally reported (Fredj \& Maurin, 1987). The family comprises closely related and poorly defined species, which makes their classification difficult. This may be the origin of some confusion, which has resulted in a poorly established geographical distribution for certain species and, consequently, scarce knowledge of this ichthyofauna in some areas (e.g. the Iberian Mediterranean coast; Matallanas, 1984a). However, recent revisions and descriptions of some genera and species belonging to this family (Desoutter,
1987, 1994; Desoutter et al., 2001) and the use of bottom trawl surveys in the Mediterranean Sea (MEDITS programme; Bertrand et al., 2000) have started to improve our knowledge of their classification.

\section{METHODS AND RESULTS}

During these surveys in 1997, 1998 and 1999, a total of 308 hauls were carried out between 30 and $800 \mathrm{~m}$ depth along the whole Iberian coast (western Mediterranean). Five specimens of Solea (Microchirus) boscanion Chabanaud, 1926 (Osteichthyes: Soleidae) were captured in three hauls

Table 1. Morphometric and meristic data of five specimens of Solea (Microchirus) boscanion captured off the Iberian coast (western Mediterranean).

\begin{tabular}{|c|c|c|c|c|c|}
\hline Number of specimen: & 1 & 2 & 3 & 4 & 5 \\
\hline Date of capture & $08 / 05 / 98$ & $05 / 05 / 99$ & $05 / 05 / 99$ & $05 / 05 / 99$ & $11 / 05 / 99$ \\
\hline Standard length (SL) & 9.7 & 8.6 & 7.6 & 7.3 & 7.9 \\
\hline Head length (HL) & 22.2 & 19.5 & 16.9 & 16.8 & 17.8 \\
\hline Eye-dorsal fin (E-D) & 1.2 & 1.2 & 1.1 & 1.0 & 1.2 \\
\hline Pectoral fin eye (PE) & 7.5 & 5.8 & 4.5 & 6.0 & 5.9 \\
\hline Pectoral fin blind (PB) & 6.0 & 4.1 & 3.5 & 3.7 & 3.9 \\
\hline Caudal peduncle (CP) & 8.9 & 8.0 & 7.1 & 6.3 & 7.2 \\
\hline Thickness $(\mathrm{T})$ & 7.0 & 6.8 & 5.7 & 5.1 & 5.9 \\
\hline Pectoral eye rays (PRe) & 5 & 5 & 5 & 5 & 6 \\
\hline Pectoral blind rays (PRb) & 4 & 4 & 4 & 4 & 5 \\
\hline Lateral line scales (LL) & 70 & 74 & 72 & 72 & 73 \\
\hline Eye-dorsal fin scales (EDE) & 4 & 3 & 2 & 2 & 2 \\
\hline
\end{tabular}




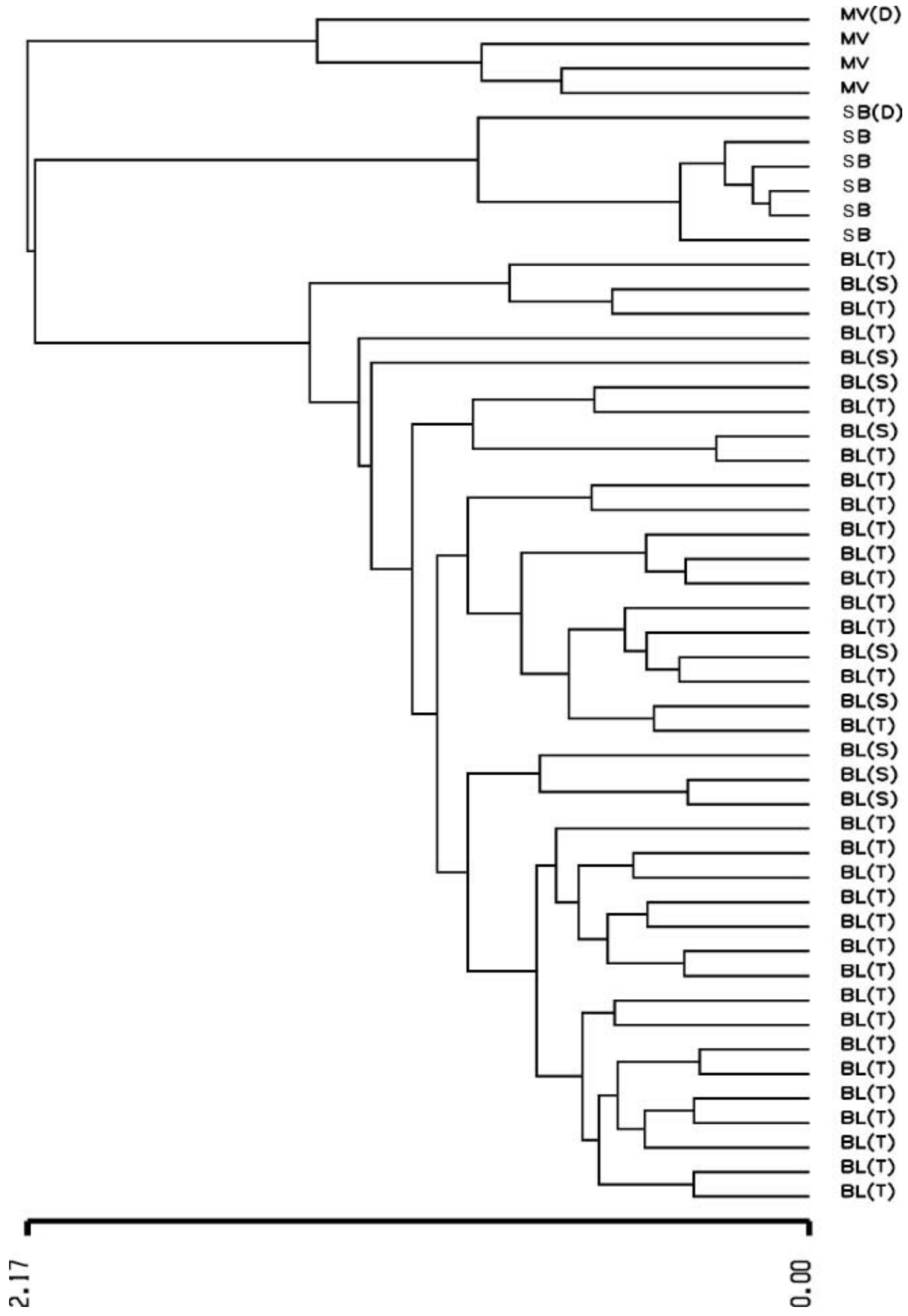

Figure 1. Cluster from morphometric and meristic data of Solea (Microchirus) boscanion, Microchirus variegatus and Buglossidium luteum specimens measured in this study and data from Desoutter (1994) for Solea (Microchirus) boscanion in the Atlantic and Microchirus variegatus in the Mediterranean and eastern Atlantic. $\mathrm{BL}(\mathrm{T})$, B. luteum from the trawl in this study; $\mathrm{BL}(\mathrm{S})$, B. luteum from the beach-seine in this study; SB, S. boscanion in this study; SB(D), S. boscanion from Desouter (1994); MV, M. variegatus in this study; MV(D), M. variegatus from Desouter (1994).

from the Alboran Sea: (i) one during June 1998 off Almería (36 $38.80^{\prime} \mathrm{N} 2^{\circ} 40.67^{\prime} \mathrm{W}, 49 \mathrm{~m}$ depth); (ii) three during May 1999 off Málaga $\left(36^{\circ} 21.06^{\prime} \mathrm{N} 5^{\circ} 12.65^{\prime} \mathrm{W}\right.$, $46 \mathrm{~m}$ depth); and (iii) one during May 1999 off Almería $\left(36^{\circ} 46.24^{\prime} \mathrm{N} 2^{\circ} 17.14^{\prime} \mathrm{W}, 63 \mathrm{~m}\right.$ depth). Moreover, the other morphologically very similar soleids Microchirus variegatus (Donovan, 1808) and Buglossidium luteum (Risso, 1810) were caught along the whole surveyed area. The number of specimens captured, their frequency of occurrence, total length range and depth range were $75,7 \%, 6-19 \mathrm{~cm}$ 
Table 2. Average morphometric and meristic data of Solea (Microchirus) boscanion, Microchirus variegatus and Buglossidium luteum specimens analysed in this study. Abbreviations from Table 1.

\begin{tabular}{|c|c|c|c|c|c|c|c|c|c|c|c|c|c|c|}
\hline & \multicolumn{4}{|c|}{ S. boscanion $(\mathrm{N}=5)$} & \multicolumn{4}{|c|}{ M. variegatus $(\mathrm{N}=3)$} & \multicolumn{3}{|c|}{ B. luteum (trawl; $\mathrm{N}=30$ ) } & \multicolumn{3}{|c|}{ B. luteum (beach-seine; $\mathrm{N}=9$ ) } \\
\hline & Mean & $(\mathrm{SD})$ & Min & Max & Mean & $(\mathrm{SD})$ & Min & Max & Mean (SD) & Min & Max & Mean $(\mathrm{SD})$ & Min & $\operatorname{Max}$ \\
\hline $\mathrm{SL} / \mathrm{HL}$ & 4.4 & $(0.1)$ & 4.3 & 4.5 & 4.5 & $(0.1)$ & 4.4 & 4.6 & $4.2(0.1)$ & 3.9 & 4.5 & $4.0(0.1)$ & 3.8 & 4.1 \\
\hline $\mathrm{SL} / \mathrm{H}$ & 2.7 & $(0.1)$ & 2.7 & 2.8 & 2.8 & $(0.2)$ & 2.6 & 2.9 & $3.0(0.1)$ & 2.7 & 3.3 & $2.8(0.1)$ & 2.7 & 2.8 \\
\hline $\mathrm{HL} / \mathrm{E}$ & 4.8 & $(0.3)$ & 4.3 & 5.1 & 4.7 & $(0.4)$ & 4.5 & 5.2 & $4.7 \quad(0.4)$ & 4.0 & 5.6 & $4.2(0.2)$ & 3.9 & 4.5 \\
\hline HL/E-D & 16.3 & (1.4) & 14.8 & 18.5 & 8.4 & $(1.0)$ & 7.3 & 9.3 & $8.7 \quad(0.9)$ & 7.3 & 11.8 & $5.7(0.8)$ & 4.7 & 6.7 \\
\hline $\mathrm{E} / \mathrm{E}-\mathrm{D}$ & 3.4 & $(0.5)$ & 2.9 & 4.2 & 1.8 & $(0.3)$ & 1.4 & 2.1 & $1.8(0.2)$ & 1.5 & 2.8 & $1.4 \quad(0.2)$ & 1.0 & 1.6 \\
\hline $\mathrm{PE} / \mathrm{PB}$ & 1.4 & $(0.1)$ & 1.2 & 1.6 & 2.0 & $(0.5)$ & 1.3 & 2.3 & $2.0 \quad(0.3)$ & 1.5 & 3.3 & $2.2(0.4)$ & 1.7 & 2.8 \\
\hline $\mathrm{SL} / \mathrm{CP}$ & 11.0 & $(0.3)$ & 10.7 & 11.6 & 10.1 & $(0.9)$ & 9.1 & 10.8 & $11.7(0.6)$ & 10.8 & 12.8 & $11.8(0.5)$ & 11.0 & 12.4 \\
\hline $\mathrm{H} / \mathrm{T}$ & 4.9 & $(0.1)$ & 4.7 & 5.2 & 4.5 & $(0.4)$ & 4.1 & 5.0 & $4.7(0.3)$ & 4.0 & 5.4 & 4.1 & 4.8 & 5.8 \\
\hline DR & 74 & $(0.7)$ & 73 & 75 & 68.3 & $(1.5)$ & 67 & 70 & $69.8(1.4)$ & 67 & 73 & $69.8(0.8)$ & 69 & 71 \\
\hline $\mathrm{AR}$ & 58.2 & $(1.5)$ & 56 & 60 & 52.3 & $(1.5)$ & 51 & 54 & $54.6(1.7)$ & 52 & 59 & $56.4(1.7)$ & 54 & 59 \\
\hline PRe & 5.2 & $(0.4)$ & 5 & 6 & 4 & $(0.0)$ & 4 & 4 & $6.2(0.8)$ & 5 & 8 & $5.7(0.5)$ & 5 & 6 \\
\hline $\mathrm{PRb}$ & 4.2 & $(0.4)$ & 4 & 5 & 3 & $(0.0)$ & 3 & 3 & $3.2(1.0)$ & 1 & 5 & $3.2(0.8)$ & 2 & 4 \\
\hline LL & 72.2 & (1.5) & 70 & 74 & 77.3 & $(2.1)$ & 75 & 79 & $62.2(3.1)$ & 59 & 69 & $62.7(4.0)$ & 59 & 69 \\
\hline EDE & 2.6 & $(0.9)$ & 2 & 4 & 4 & $(0.0)$ & 4 & 4 & $3.5(0.5)$ & 3 & 4 & $3.5(0.5)$ & 3 & 4 \\
\hline
\end{tabular}

AR, anal fin rays; CP, caudal peduncle; DR, dorsal fin ray; E, eye diameter; E-D, eye-dorsal fin; EDE, eye-dorsal fin scales; $\mathrm{H}$, maximum height; HL, head length; LL, lateral line scales; N, number of specimens analysed; PB, pectoral fin blind; PE, pectoral fin eye; PRb, pectoral blind rays; PRe, pectoral eye rays; SL, standard length; T, thickness. N, number of specimens analysed; $\mathrm{SD}$, standard deviation; Min, minimum; Max, maximum.
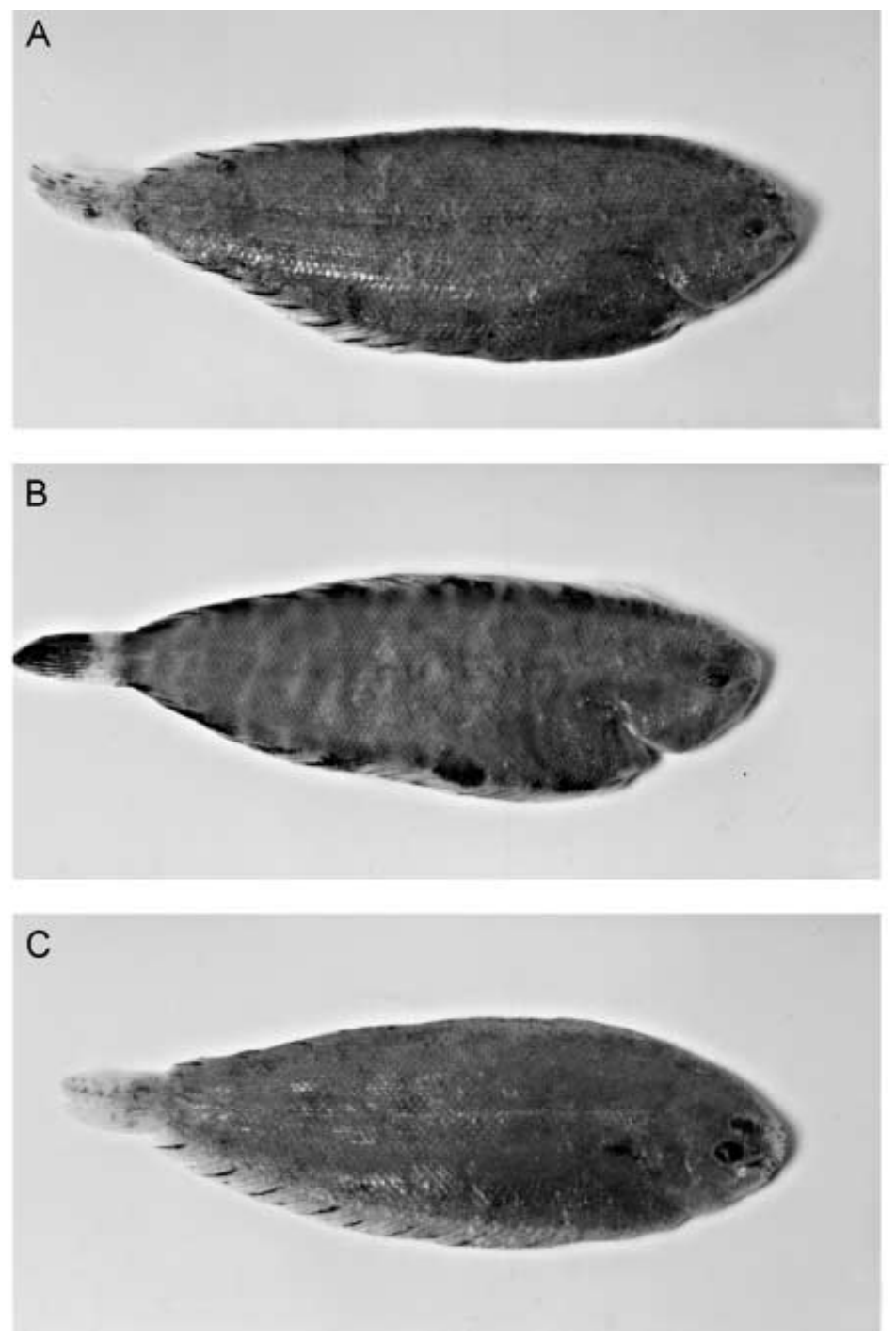

Figure 2. Photographs of specimens of (A) Solea (Microchirus) boscanion; (B) Microchirus variegatus; and (C) Buglossidium luteum captured off the Iberian coast (western Mediterranean). 
and $47-647 \mathrm{~m}$ for $M$. variegatus and $122,3 \%, 7-12 \mathrm{~cm}$ and 38-77 $\mathrm{m}$ for $B$. luteum respectively.

In addition, other individuals of Buglossidium luteum were captured from more inshore waters of the Alboran Sea with beach-seine (118 hauls made between 1980 and 1983 from a depth of 1 to 10 m; Reina-Hervás, 1987) and Agassiz trawl (43 hauls made from October 1996 to October 1997 between depths of 12 and $16 \mathrm{~m}$ ). The number of specimens captured, their frequency of occurrence, total length range and depth range were $128,51 \%, 4-12 \mathrm{~cm}$ and $1-10 \mathrm{~m}$ for beach-seine and 101, 72\%, 2-8 cm and 12-16 m for Agassiz trawl.

In the laboratory, morphometric and meristic characters were measured according to Desoutter (1987, 1994), although the count of fin rays was difficult because they were split. The coloration of fresh individuals was also noted.

To corroborate the systematic position, the standardized morphometric and meristic characteristics of the specimens were compared to the average values for Solea (Microchirus) boscanion and Microchirus variegatus reported by Desoutter (1994) from the eastern Atlantic and the Mediterranean specimens. The quantitative average taxonomic distance, one of the most common indices utilized in numerical taxonomy (Rohlf, 1992), and the unweighted pair-group method using arithmetic averages (UPGMA) algorithm were used.

Morphometric and meristic data for Solea (Microchirus) boscanion specimens (deposited in the Institut de Ciencies del Mar Fish Collection) are presented in Table 1. Although S. boscanion, Microchirus variegatus and Buglossidium luteum are morphologically very similar, the cluster dendrogram (Figure 1) distinguished them from each other and confirmed that they belonged to the different species considered. The average morphometric and meristic characters of each species by method of capture are shown in Table 2.

The main characteristics used to distinguish these soleid species were the following: (i) Solea (Microchirus) boscanion and Microchirus variegatus have a caudal fin completely separated from the dorsal and anal fins, while Buglossidium luteum has a thin membrane between the dorsal and anal fins (Quéro et al., 1986); (ii) the distance between the upper eye and dorsal fin in B. luteum is greater than in S. boscanion (Desoutter, 1987). In addition, S. boscanion and $M$. variegatus could be distinguished by their different coloration patterns (Figure 2). Microchirus variegatus showed broad dark cross-bands on the body, and on the dorsal and anal fins of the eyed side, whereas S. boscanion had smaller dark spots on the edge of the eyed side, as well as on the dorsal and anal fins, and every fourth to sixth finray of these fins were dark. Buglossidium luteum showed a more similar coloration to $S$. boscanion, but with every fourth to seventh finray being dark.

\section{DISCUSSION}

Solea (Microchirus) boscanion is distributed throughout the eastern Atlantic from the Gulf of Cadiz to the Gulf of Guinea (Fischer et al., 1981; Quéro et al., 1986). It is the first report of the species in the Mediterranean and represents the fourth report of soleid species from the eastern Atlantic recently found in the western Mediterranean.
The first of these species was Synaptura lusitanica, reported by Lozano-Rey (1960) off the Central Iberian Peninsula. Subsequently another two species have been reported, Solea senegalensis off the Iberian coast (Rodríguez \& Rodríguez, 1980), a species which has progressively extended its distribution (Quignard \& Raibaud, 1993), and Microchirus hexophthalmus (Matallanas, 1984b).

Alien fish species recorded from the Mediterranean Sea have attracted much scientific attention in recent years (Golani et al., 2002), especially the numerous reports of lessepsian migrants (Golani, 1996). Nevertheless, a considerable number of typical Atlantic species has been reported recently in the western Mediterranean, and some authors have speculated that the recent increase in imports of tropical species via Gibraltar is supported by hydroclimatic modifications (Quignard \& Tomasini, 2000).

Although other reasons, such as recent taxonomic improvements, can also be considered (Matallanas, 1984a), the above mentioned changes in hydroclimatic conditions could be the origin of the presence of Solea (Microchirus) boscanion in the Mediterranean. The fact that specimens have been captured in different hauls and years, supports the idea of possible stable populations of this species in the Mediterranean. This new species in the area, could affect the other sympatric soleid species Microchirus variegatus and Buglossidium luteum, which are indigenous to the Mediterranean. Therefore, it will be necessary to analyse certain biological aspects of these species in order to determine their degree of niche overlapping or partitioning.

Until now, the geographical distribution of Solea (Microchirus) boscanion, Microchirus variegatus and Buglossidium luteum in the Mediterranean has overlapped in the area closest to the Atlantic ocean: while $S$. boscanion was restricted to the Alboran Sea, M. variegatus and B. luteum were also caught further north on the Iberian coast. Their bathymetric range also overlaps, with $B$. luteum and $M$. variegatus being the shallowest and deepest species, respectively. Over the continental shelf, both species have been caught with the bottom trawl on coastal detritic muddy and sandy bottoms. Buglossidium luteum is additionally captured in inshore areas over Zostera marina sea grass meadows on sand and muddy bottoms sampled with the Agassiz trawl and the beach seine. Microchirus variegatus shows the widest bathymetric range, as it was additionally caught with the bottom trawl over the continental slope.

Data on the diet and reproduction of Solea (Microchirus) boscanion are absent, whereas they are scarce for Buglossidium luteum and Microchirus variegatus (Quéro et al., 1986; Bauchot, 1987). For this reason, it is difficult to evaluate the colonization success of the Atlantic species and further studies will be necessary. Nevertheless, it must be taken into account that the two Mediterranean species probably exploit the same trophic resources (i.e. small bottom-living organisms of mainly crustaceans, bivalve molluscs and polychaetes) and spawn around the same period (winter-spring), although they are distributed in different habitats, shallower and deeper, respectively. Consequently, the establishment and expansion of S. boscanion in the Mediterranean could depend on its capacity to colonize any probable vacant spatial and temporal niche between these native sympatric soleids. 
We thank C. Allué for providing soleid specimens, Bàrbara Sansó for providing photographs and Dr C. Rodgers for help with improving the English. This paper is a result of the following Spanish and European Projects: MEDITS (DGXIV/IEO/ 054), DGICYT PB97-1116 and MAR98-1706-E.

\section{REFERENCES}

Bauchot, M.L., 1987. Poissons osseux. In Fiches FAO d'identification des espèces pour les besoins de la pêche. Mediterranée et Mer Noire. Zone de pêche 37, Révision 1, Vol. II, Vertébrés (ed. W. Fischer et al.), pp. 891-1422. Rome: FAO.

Bertrand, J.A., Gil de Sola, L., Papaconstantinou, C., Relini, G. \& Souplet, A., 2000. An international bottom trawl survey in the Mediterranean: the MEDITS programme. In Demersal resources in the Mediterranean (coordinators J.A. Bertrand and G. Relini). Actes de Colloques, 26, 76-93.

Desoutter, M., 1987. Status de Microchirus boscanion Chabanaud, 1926 et de Buglossidium luteum (Risso, 1810) (Pisces, Pleuronectiformes, Soleidae). Cybium, 11, 427-439.

Desoutter, M., 1994. Révision des genres Microchirus, Dicologlossa et Vanstraelenia (Pleuronectidae, Soleidae). Cybium, 18, 215-249.

Desoutter, M., Chapleau, F., Munroe, A., Chanet, B. \& Beaunier, M., 2001. Catalogue critique des types de poissons du Muséum National d'Historie Naturelle. Ordre des Pleuronectiformes. Cybium, 25, 299-368.

Fischer, W., Bianchi, G. \& Scott, W.B., ed., 1981. Fiches FAO d'identification des espèces pour les besoins de la pêche. Atlantique centre-est; zones de pêche 34, 47 (en partie). Ottawa: Ministère des Pêcheries et Océans Canada \& FAO.

Fredj, G. \& Maurin, C., 1987. Les poissons dans la banque de données MEDIFAUNE. Application a l'étude des caracteristiques de la faune ichthyologique Méditerranenne. Cybium, 11, 219-299.
Golani, D., 1996. The marine ichthyofauna of the eastern Levant-history, inventory and characterization. Israel fournal of Zoology, 42, 15-55.

Golani, D., Orsi-Relini, L., Massutí, E. \& Quignard, J.-P., 2002. CIESM Atlas of exotic species in the Mediterranean. Vol. 1. Fishes (ed. F. Briand), pp. 1-256. Monaco: CIESM Publishers.

Lozano-Rey, L., 1960. Peces fisoclistos. Tercera Parte. Subseries Torácicos (Ordenes Equeneiformes y Gobiformes), Pediculados y Asimétricos. Memorias de la Real Academia de Ciencias Exactas, Físicas y Naturales, Madrid, serie Ciencias Naturales, no. 14, 1-613.

Matallanas, J., 1984a. Consideraciones sobre algunos pleuronectiformes (Pisces, Teleostei) nuevos o de dudosa presencia en las costas orientales ibéricas. Miscellània Zoològica, 8, 197-202.

Matallanas, J., 1984b. A new species for the Mediterranean and Spanish ichthyofauna: Dicologlossa hexopthalma (Bennett, 1831) (Pisces, Soleidae) from Catalan waters. Cybium, 8, 95-96.

Quéro, J.-C., Desoutter, M. \& Lagardère, F., 1986. Soleidae. In Fishes of the North-eastern Atlantic and the Mediterranean (ed. P.J.P. Whitehead et al.), pp. 1308-1324. Paris: UNESCO.

Quignard, J.P. \& Raibaut, A., 1993. Ichthyofaune de la côte languedocienne (Golfe du Lion). Modifications faunistiques et démographiques. Vie et Milieu, 43, 191-195.

Quignard, J.P. \& Tomasini, J.A., 2000. Mediterranean fish biodiversity. Biologia Marina Mediterranea, 7, 1-66.

Reina-Hervás, J.A., 1987. Análisis de la ictiofauna infralitoral en el sureste español (Mediterráneo Occidental). Cahiers de Biologie Marine, 28, 73-89.

Rodríguez, A. \& Rodríguez, R.B., 1980. Primera cita en el Mediterráneo de Solea senegalensis Kaup, 1858 (Heterostomata, Soleidae). Investigación Pesquera, 44, 291-295.

Rohlf, F.J., 1992. NTSYS-pc. Numerical taxonomy and multivariate analysis system. Ver. 1.70. New York: Exter Software.

Submitted 18 January 2002. Accepted 27 August 2002. 